\title{
三塩化エチレン作業者の実態補遺
}

\section{A supplement of a survey on Trichloroethylene workers}

\author{
横浜市立大学医学部衙生学教室 (教授 䕛原兼交) \\ 山賀岺朗猿田勝美大 森撸 \\ Shinro Yamaga, Katsumi Saruta, Kaoru Omori, \\ 望月武治橋口明男石田詮 \\ Takeharu Mochizuki, Akio Hashiguchi Kano Ishida
}

Department of Hygiene, Yokohama University School of Medicine

三監化エチレン（以下トリクレンと略記する）作業者 の実態について, 当教室より昭和28年に山賀が労㗢科学 誌上に発表したが"，その後さらに，若干資料を加えた ので，その中でとくに血液及び尿の形態学的所見を中心 として検討した結果を報告したい。

\section{I. 調 查対象}

昭和 26 年より 34 年にいたる間の調査資料に基くもの で，対象はトリクレンの製造に従事する者と，トリクレ ンを用いて脱脂，洗條を行う者とで，合計52名である。 これらはいずれも当教室においての及得られた資料であ る。

これらの作業環境条件，とくにトリクレンへの曝露 状況については, 先に衞生学雑誌に発表した 通りであ $ろ^{2)}$ 。

\section{II. 調查項目および方法}

調查項目は後揭図 2 に記載の通りである。調查の方法 㹥, 調査の期間が数年間にまたがっているので必ずしも 統一されてはいないが, その主要な項目についての検査 方法は次の通りである。

1）血液比重は硫酸銅法によった。但しこの場合，血

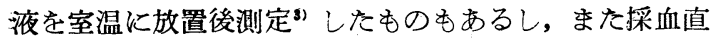
後の測定もある。

2）血球数算定は, メランジュール法及び試験管法を 拥いた。

3）塩基性顆粒赤血球数の算定は，薄層塗抹標本の May-Giemsa 染色, また汹タノール固定, Giemsa 染
色によった。

4）血色素量は，硫酸銅法による血液比重より換算" あるいはシアンメトへモグロビン法可によった。

5）へマトクリット値は, 硫酸銅法による血液比重よ り換算") あるいは実測（3000迴転，30分間）によった。

6）尿蛋白及びウロビリノーゲンは城生検査指針 VK 従っだ)。

7）尿コプロポルフィリンは Brugsch 法7-9)によっ た。

8）トリクロール酶酸（所謂藤原反応陽性物質）は Frant and Westendorp 法 ${ }^{10)}$ ，亦るいは山賀等の簡易 法"1)によった。

因 1 年数と勤繶年数

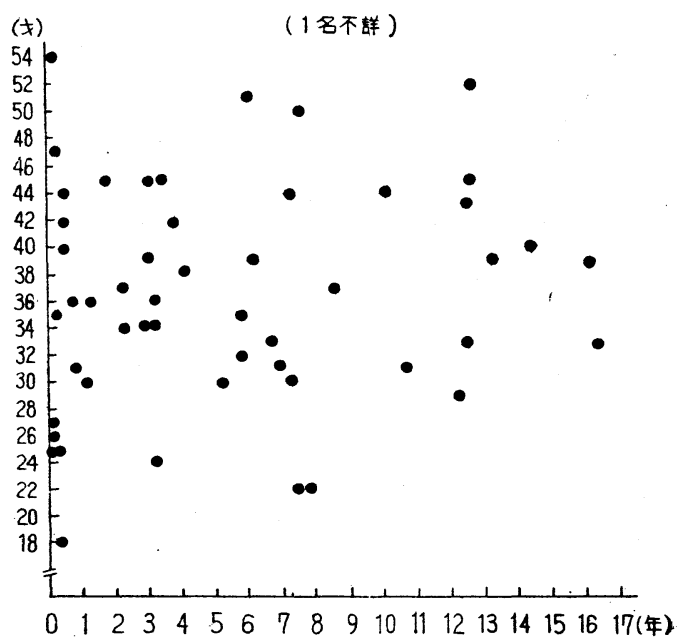




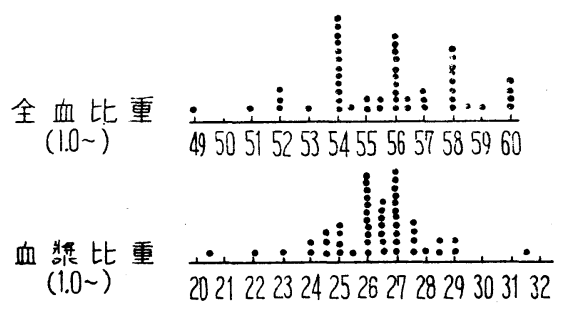

赤血球数

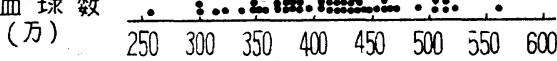

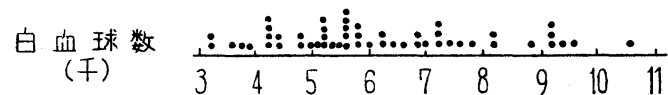

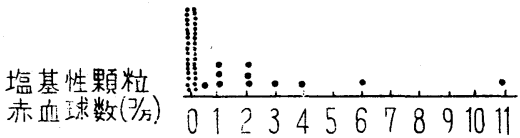

血色素量 $(8 / 22)$

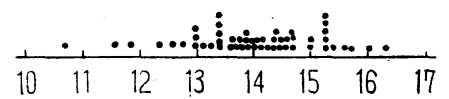

\section{III. 調 查結果}

調査対象の年令及び勤続年数は図 1 亿, 諸検査の成績 を図 2 に示した。

これらの結果を, 平均値, 及び産業衛生協会で主とし て用いられている纳の生理値 ${ }^{12,13)}$ 亿準拠した異常率を以 て示すと表 1 の通りである。

図 3 より図13は，各項目毎に勤続年数別に示したもの で, 仮りに 5 年毎の区分による平均値の検討では,トリ クロール酰酸排泄量の項目のみに，5.0年と 5 年 1 月以 上との間の有意差 $(\alpha=0.01)$ がみとめられた。

またてれらを, 前記基淮(表 1 記載)に基く異常率で, 5 年毎の 勤続年数区分によって検討する と表 2 の通り で, 血墏比重の减少が 5.0 年以下と 5 年 1 月以上との間 て，ウロビリノーグンの陽性が 10.0 年以下と 10 年 1 月以 上との間で，それぞれ $5 \%$ の危険率で有意差がみこめら れた。

\section{IV. 考察および総括}

トリクレン作業によって現実にどのような変化があら われているかどうかという実態を明かにするととは，当 該作業の健康管理上最も重要な点である。とくに衞生学 の領域で職業病の特殊健晾, とりわけふるい分け検査を
イマトフリット值 . ....... .

(\%) $\quad 3334353637383940414243444546474849$

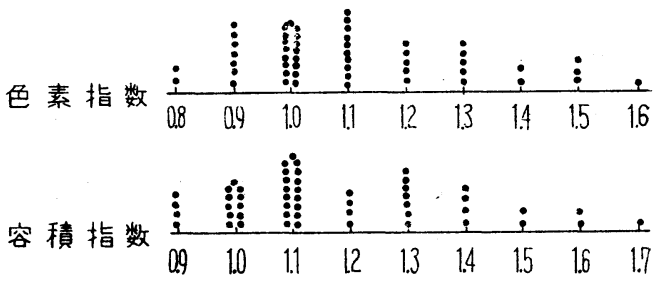

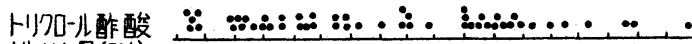

排泄量(畔) 0102030405060708090100200300405500600700800900

\begin{tabular}{|c|c|c|c|c|}
\hline & - & $(+)$ & $(-)$ & 計 \\
\hline \multirow{3}{*}{ 尿 } & 由 & 4 & 48 & 52 \\
\hline & ウロビリノーゲン & 35 & 17 & 52 \\
\hline & コプロポルフィリン & 9 & 39 & 48 \\
\hline
\end{tabular}

行うに当っては, 実験的中毒によって可能性のあると思 われる所見より，作業者の実態に沶いてみとめられる所 見の方が，より重点的である。さらに，とくにふるい分 け検查に利用せんをする場合には，測定方法に执いて も, また出現頻度に执いても, より以上普遍的, 簡易な 所見を求めるべきであろう。

このような意図から，てこでは血液及び尿の形態学的 所見に重点を抬いて検討するとととした。

血液の形態学的所見その他については, 実は従来, 変

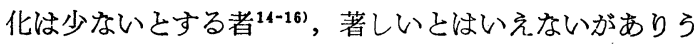
るとする者1,17-22) とがあるようである。そのような違い はえられた対象の作業環境条件の差によって当然であ。 り，いずれもがそれぞれ正しいと思われる。

しかし，ありとする報告のある以上，たまたまえられ， た対象に著変がなかつたからといって, トリクレンによ り身体変化は少ないとするととは慎重を要し，ありうる。 かも知れないとする保留もまた必要であろう。

このいづれがょり正確に近いだろろか，さらにまた， 身体変化があるとすると，どのような項目であるか等を 知る目的で, 著者等の調査の範囲内に招ける検討を企て た。

その結果は前記の通りで, 吾々としては従来通り, ト リクレンによって血液や尿の変化が扔こりうるとする態 
表 1 平均值ちよび塁学率

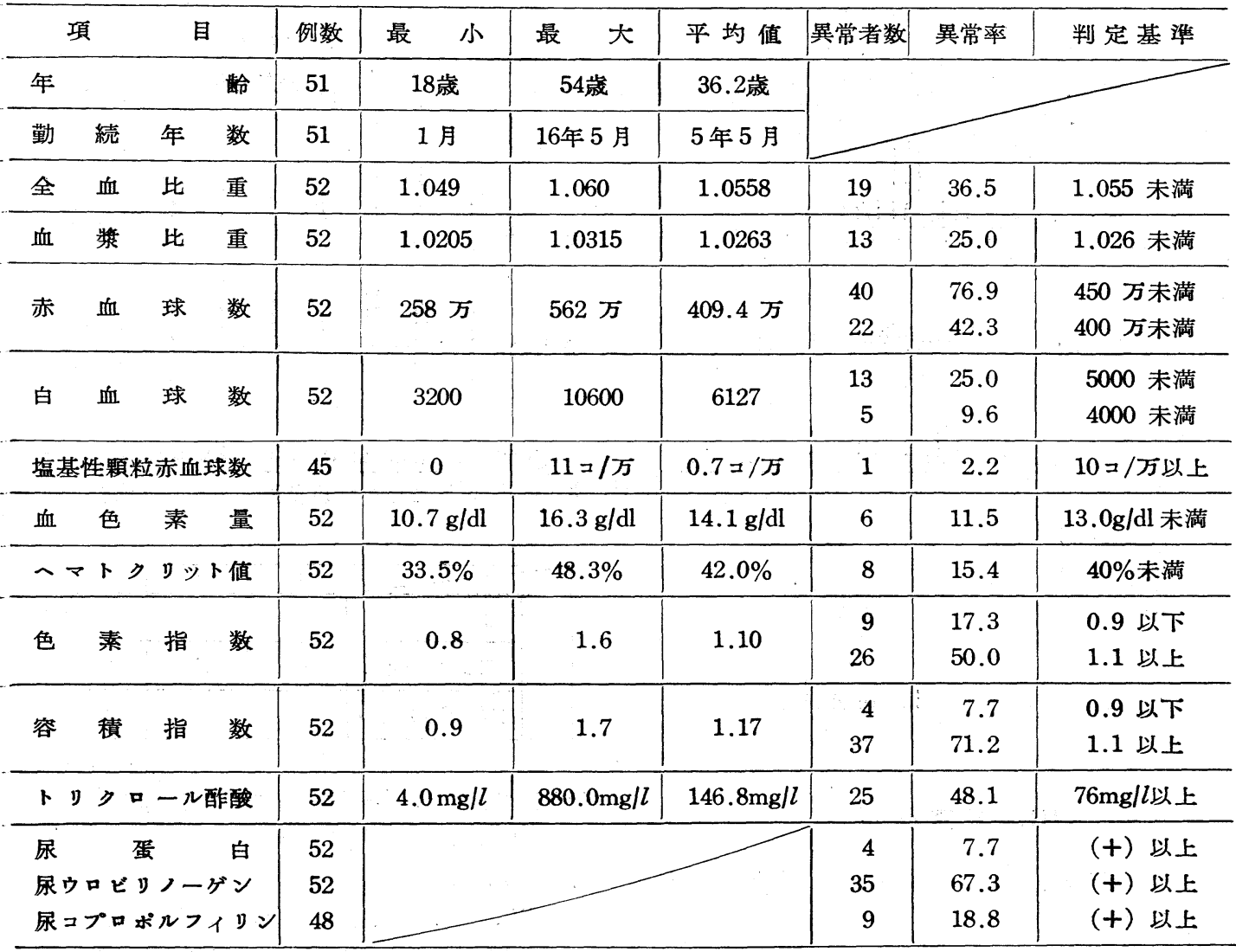

度を表明するものである。

すなわち, 平均値によっては, 色素指数, 容積指数, トリクロール酢酸量が, 所謂基準值をこしている程度て あるが, 異常と目される者の割合からは, 赤血球数, 容 積指数, 色素指数, ウロビリノーゲン, トリクロール酢

因 3 全血比而と䓵挖年数

( 1 名不詳)

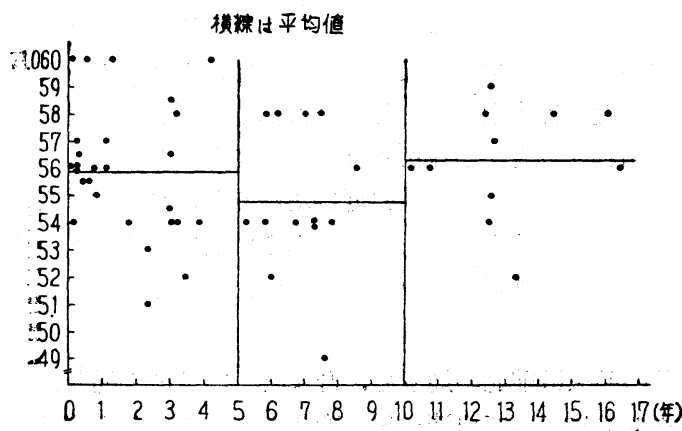

酸量等の異常が比較的多いといえよう。

ととに赤血球数については，450万に基準をとると約 77\%にも低下がみとめられ，400万を基淮としても約42 \%に低下がみられる。とれに対して, 血色素量やへマト クリット值の減少は少く, 従つて色素指数や容積指数は

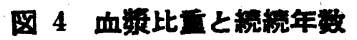

( 1 名不詳)

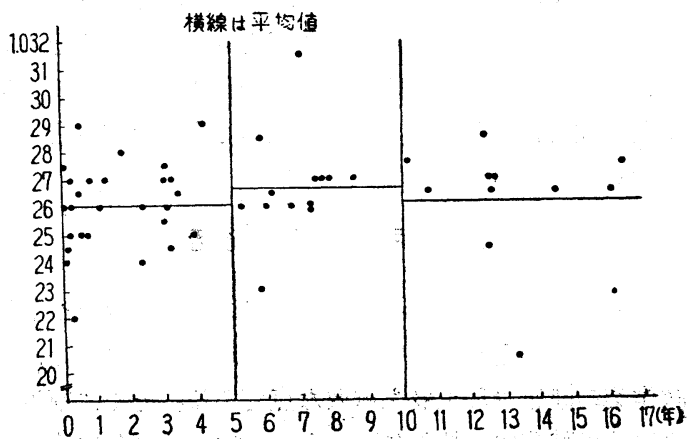


図 5 赤血球数と勤繶年数（1名不詳）

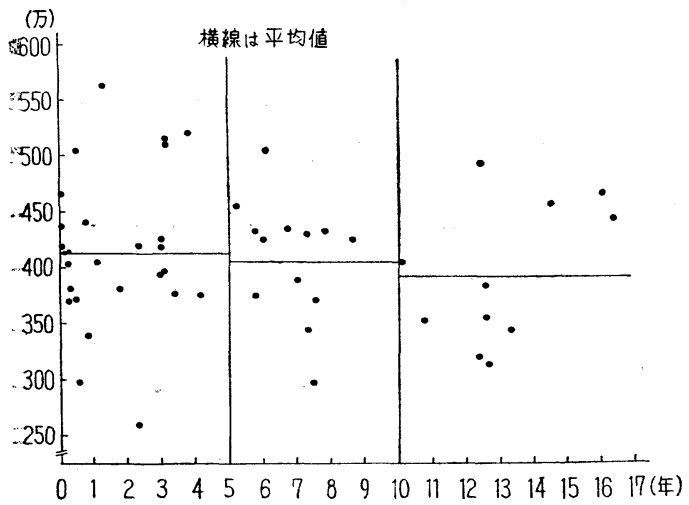

図 7 塻基性頛粒赤血球数と䓵綂年数

( 7 名不詳)

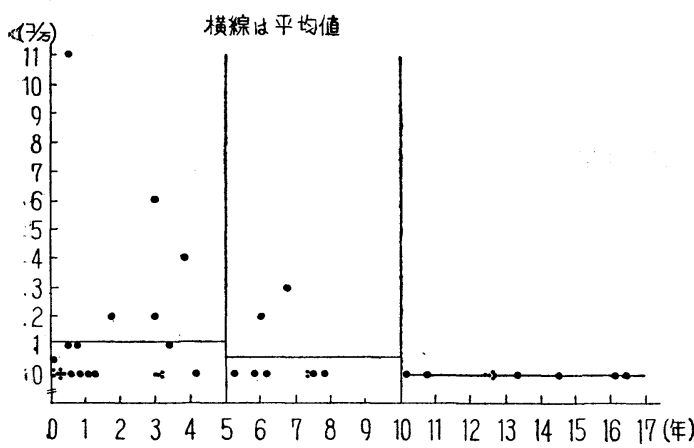

図 9 ヘマトクリット值と䓵转年数

(1 名不詳)

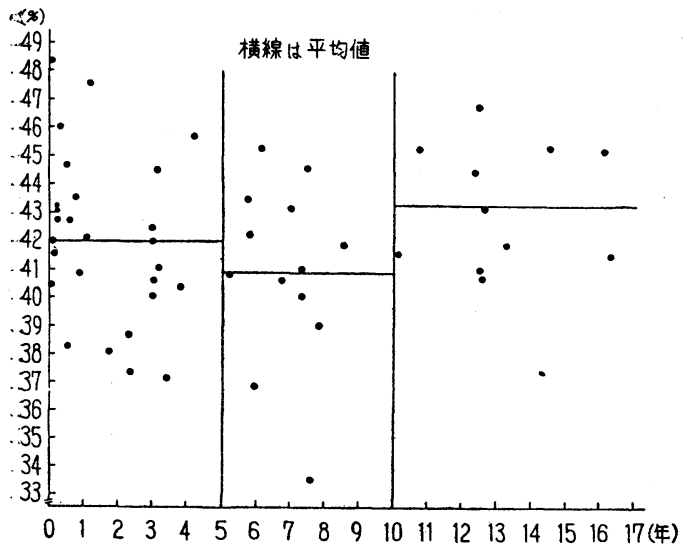

大きく，いわば高色素性, 大球性䝱血の型をとるととが 多いようである。この点はベンソール等の有機溶剤中毒 《包含される所見ともいえるようでるが, しかし白血
図 6 由血球数と勤繶年数（1 名不詳）

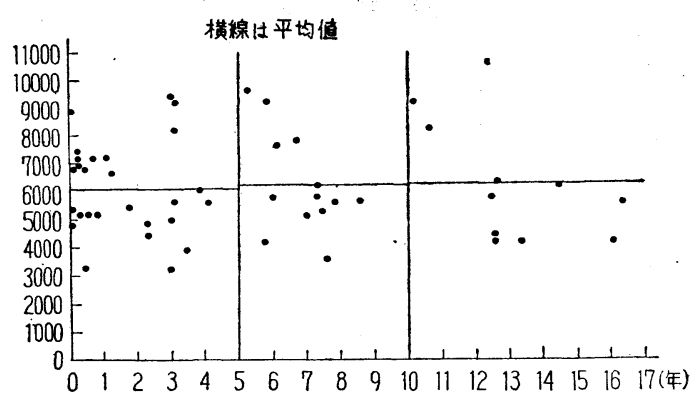

図 8、血色素量と䓵綂年数（1 名不詳）

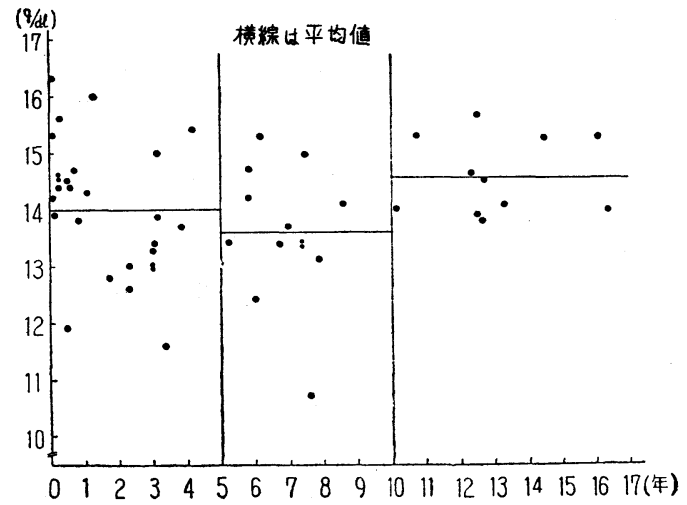

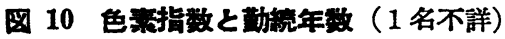

横線は平均値

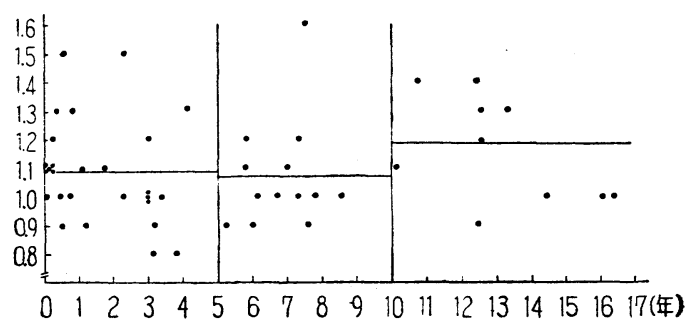

因 11 容稜指数と勤繶年数（1 名不詳）

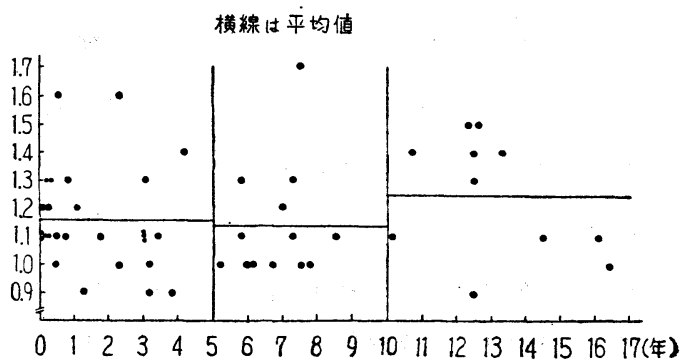




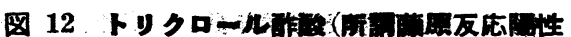
物票) 排泄量と勤綂年数（1 名不解）

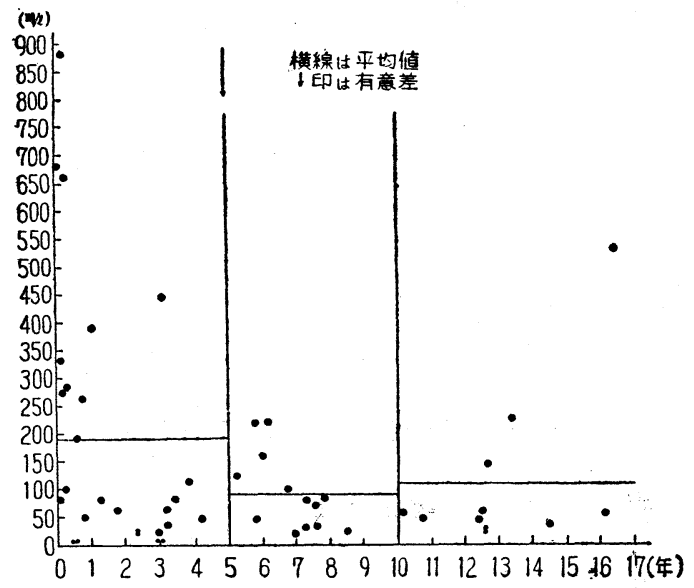

球数の減少を呈する者は少く，少くともぶるい分け検査 項目としての価値は少ないもののごとく思われる。

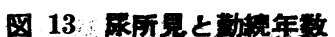

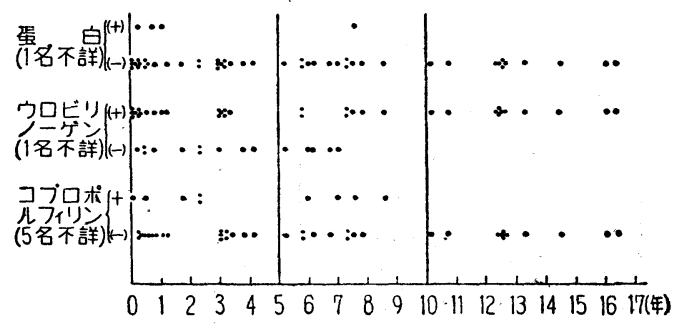

各項目の 5 年毎の平均值の勤続年数別の検討結果 で は,トリクロール醀酸の項を除いて,いずれも有意の差は みとめられなかつた。トリクロール醀酸量については, 勤続の短い群の方が平均值で有意の增大があったことは

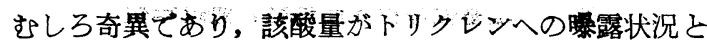
比例するとすると, トリクレン作業では勤続年数が長い 者はむしろトリクレンへの曝露が少いという，作業上の 若干の特長も想像される。

表 2 異常と目される者の鹳綂年数别梌討

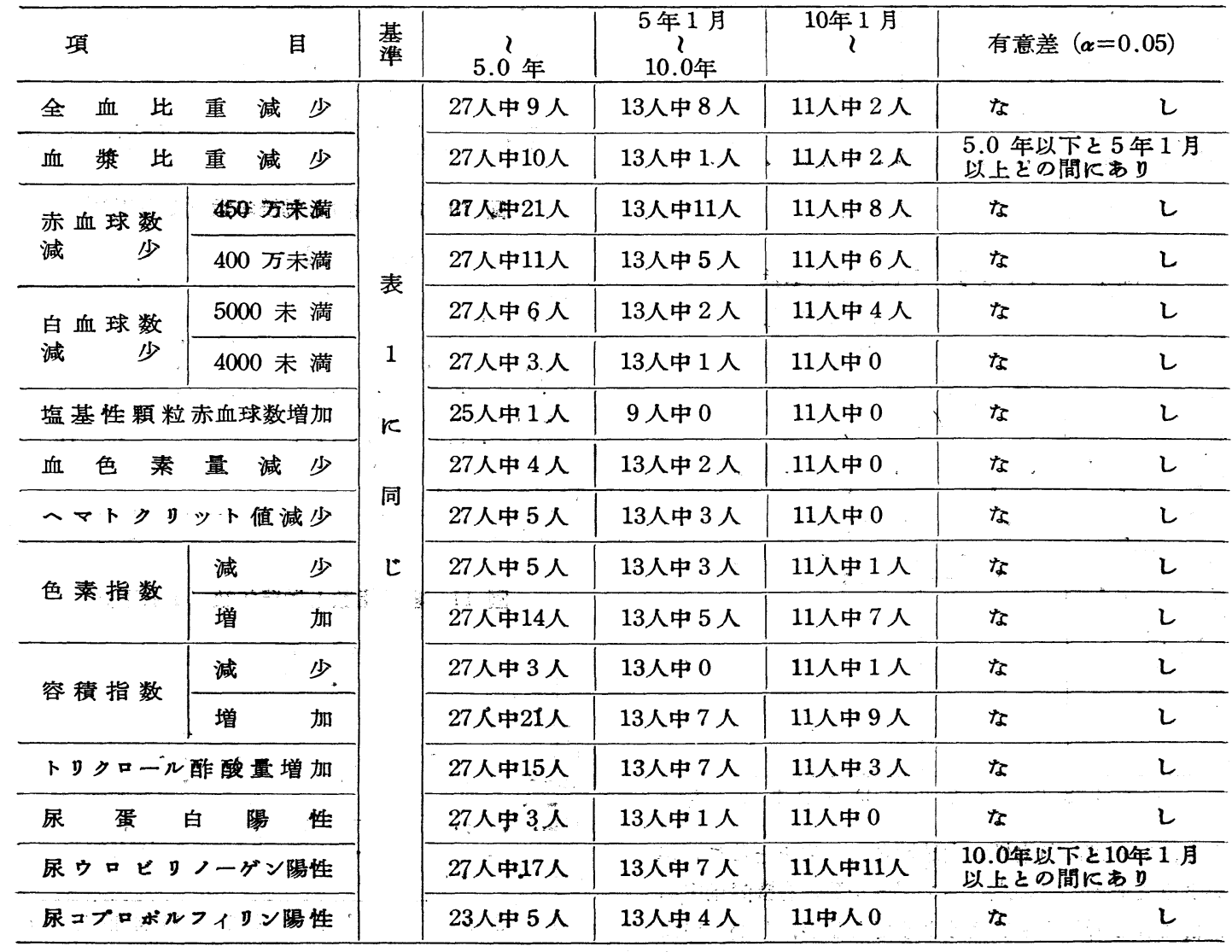


一般にトリクレンの作用は比較的速かで，著しい蓄積 作用は少い上うに考えられ，平均值の勤続年数別の検討 結果はこれを裏付けるものといえるが，一方，異常と目 される者の 5 年毎の勤続年数別の検討で, ウロビリノー ゲンの陽性者が勤続10年をこすと有意に增加している点 は,トリクレン作業と勤続の長さとに対する関連を無視 すべきでないととを示唆するものといえよう。

ここで血漿比重の減少者が勤続の早期に有意汇多かっ たととは，な打今後の検討の余地があると思われる。

以上，トリクレン作業者の実態について，とくにその 特殊健診，とりわけふるい分け検査に資する意図の下に 検討を行った。

その結果，次の諸点がみとめられる。

1）トリクレン作業によって，血液や尿の変化が抬て りろる。

2）血液については赤血球数の減少の可能性が最も価 值ある所見であり，しかもその賀血の型は高色素性，大 球性であるここが多い。

3）尿については，ウロビリノーゲンとトリクロール 酢酸（所謂藤原反応陽性物質）とが主要な所見である。

4）勤続年数別には，勤続の短い群のトリクロール酶 酸量の平均値が有意に高く, 血漿比重の減少者が勤続の 短い群に，ウロビリノーゲンの陽性者が勤続の長い群 に，それぞれ有意に多いととがみとめられた。

終りに萩原教授の御校閲に深謝する。

本研究には昭和 34 年度, 労働省労衝衛生試験研究費 の補助をらけた。附記して謝意を表する。

\section{交 献}

1) 山賀岑朗 : 労働科学 $29(3), 119-125$, 昭 28 .

2）萩原兼交他：日本衛生学雑誌 $11(5), 273-274$ 昭 31.

3）職業病検診法研究会 : 医学のあゆみ $30(5), 273$ -279 , 昭 34 .

4）吉川春寿 : 硫酸銅法, 40, 東京, 昭 25 .

5）暒田昭彥. 他 : 化学の領域増刊 33, 131-136, 昭 33.

6）厚生省編：衛生検查指針 $\mathrm{V}$ ，臨床検查指針，東 京, 1950 .

7）金井泉他：臨床検查法提要， 25, 東京, 昭 25 .

8）西野俊策 : 労働科学 $26(12), 525-530$, 昭 25 .

9）勝沼晴雄他編：職業病検診の手技，尿 1-3, 東 京, 昭 31 .

10) R. Frant and J. Westendorp: Arch. Indust. Hyg. and Occup. Med., 1(3), 308-318, 1950.

11) 山賀岑朗, 他 : 日本衛生学雑誌 $13(1), 140$, 昭 33.

12）（9）と同書の附 37.

13）特殊健診検討委員会経過報告：産業医学 1(2). 187-188，昭 34 .

14) 松藤元 : 労働科学 $32(4), 273$, 昭 31 .

15）堀内一彌他: 労働科学 $32(4), 273$, 昭 31 .

16）青木九一郎他：労㗢科学 $32(4) ， 4$, 昭 33 .

17）山賀岑朗他：労働科学 $29(7), 395-399$, 昭 28 .

18）藤井徹他：労働科学 $31(4), 215$, 昭 30.

19）堀内一彌他：労働科学 $33(7), 543$, 昭 32 .

20) 片山球 : 労働科学 $34(2), 79-89$, 昭 33 .

21）館正知他: 労働科学 $34(4), 6$, 昭 33 .

22) 大田原一祥. 他 : 岡山医学会雑誌 $70(11)$, 40814087, 1959.

（受付：1960 年 8 月 22 日) 